\title{
Д. Мальшева
}

\section{ВОЕННО-ПОЛИТИЧЕСКАЯ ОБСТАНОВКА НА КАСПИИ}

DOI: 10.20542/2073-4786-2019-2-56-66

Каспий - крупнейший на земле замкнутый водоем, не имеющий прямого выхода к Мировому океану, но связанный с Азовским и Черным морями Волго-Донским судоходным каналом, который является важным звеном сформированной к 50-м годам XX в. системы внутренних водных путей России («Единая глубоководная система Европейской части Российской Федерации»).

Геополитическая значимость Каспия обусловлена рядом факторов. Во-первых, наличием на морском шельфе и под морским дном значительных нефтяных и газовых ресурсов (до 6,5 млрд т доказанных и вероятных запасов нефти и газа в нефтяном эквиваленте, согласно оценкам Службы энергетической информации США [1]). Во-вторых, транзитным потенциалом, возможностью соединения морскими путями Центральной Азии и Южного Кавказа для поставок энергоносителей и других товаров через существующие и планируемые транспортные коридоры. В-третьих, выгодным военно-стратегическим положением, позволяющим контролировать сферу безопасности как в Центральной Азии и на Кавказе, так и на Ближнем Востоке.

До 1991 г. Каспий фактически являлся внутренним морем двух государств - СССР и Ирана. Правовой режим регулировался договорами - между РСФСР и Персией от 1921 г., между СССР и Ираном (1935 и 1940 гг.). Кроме того, с 1934 г. на Каспии в одностороннем порядке Советским Союзом была установлена граница по линии Гасан-Кули (Туркмения) - Астарачай (Азербайджан), негласно признававшаяся Ираном. СССР руководствовался при этом задачами обеспечения своей военной безопасности - Иран вплоть до исламской революции 1979 г. находился в зоне влияния США, которые, благодаря союзническим отношениям с шахским режимом, стремились использовать в своих интересах территориальную приближенность Ирана к южным районам Советского Союза. Впрочем, на неоднократные предложения США разместить их военные базы вблизи сухопутной границы Ирана с СССР или на иранском побережье Каспия шах Мохаммед Реза Пехлеви каждый раз отвечал отказом, поскольку не хотел портить отношения со своим могущественным соседом. 
Распад СССР и образование неформального объединения - «каспийской пятерки» (в составе Азербайджана, Ирана, Казахстана, России и Туркменистана) положили начало дискуссии о разделе сфер влияния на Каспии и переговорам о его статусе. В 2001 г. Россия и Иран заключили договор, который, согласно статье 12, обязывал стороны «до усовершенствования правового режима Каспийского моря» официально не признавать там никаких границ [2]. С Казахстаном и Азербайджаном Россия договорилась к началу 2000-х гг. о разделе дна моря с целью недропользования по принципу модифицированной срединной линии.

В то же время Южный Каспий, на территории которого имелось несколько крупных нефтегазовых месторождений, остался зоной противоречий между Азербайджаном, Туркменистаном и Ираном. Однако до вооруженных столкновений, кроме нескольких инцидентов [3, с. 20-21], дело между ними не дошло, и спорные вопросы прикаспийские государства решали в основном дипломатическим путем - на регулярных встречах министров иностранных дел и президентов.

Первый Каспийский саммит прошел 23 апреля 2002 г. в Ашхабаде, не приведя, правда, к сколько-нибудь значимым сдвигам в решении назревших проблем. Результативнее оказалась состоявшаяся 16 октября 2007 г. в Тегеране вторая встреча на высшем уровне - на ней стороны зафиксировали свои суверенные права на Каспий и его ресурсы, обязались не предоставлять свою территорию третьим странам. Третий и четвертый саммиты прошли, соответственно, 18 ноября 2010 г. в Баку и 29 сентября 2014 г. в Астрахани, где президенты пяти прикаспийских государств заявили о том, что их деятельность будет осуществляться «на основе согласованных ими принципов, в том числе... неприсутствия на Каспийском море вооруженных сил, не принадлежащих Сторонам» [4]. Самой же результативной оказалась встреча на высшем уровне 12 августа 2018 г. в Актау (Казахстан): на ней был принят исторический документ - «Конвенция о правовом статусе Каспийского моря».

«Конвенция» не только определяет, но и гарантирует условия для совместной политической, военной, экономической и экологической деятельности «прикаспийской пятерки». В соответствии с включенным в документ положением о недопущении присутствия на Каспии вооруженных сил третьих стран, прикаспийские государства обязуются не предоставлять свою территорию кому-либо «для совершения агрессии и других военных действий против любой из сторон», и намерены обеспечивать «стабильный баланс вооружений на Каспийском море», «осуществлять военное строительство в пределах разумной достаточности с учетом интересов всех сторон» [5]. При этом приоритеты прибрежных государств в сфере противодействия 
на Каспии как традиционным военным угрозам, так и нетрадиционным вызовам - нелегальной миграции, контрабанде оружия, транспортировке наркотических средств, браконьерству - в целом совпадают.

Подходы России к взаимодействию со своими партнерами в Каспийском регионе выстраиваются, согласно статье 60 действующей «Концепции внешней политики Российской Федерации» (утверждена Указом Президента РФ 30 ноября 2016 г.), «с учетом необходимости укрепления механизма сотрудничества пяти прикаспийских государств на основе коллективно принимаемых ими решений» [6]. В другом документе, определяющем на период до 2030 г. основы государственной политики РФ в области военно-морской деятельности, необходимость присутствия России в бассейне Каспийского моря объясняется усиливающимся стремлением ряда государств к обладанию там «источниками углеводородных ресурсов» [7, пункт 27 «а»].

Российская Каспийская флотилия (КФ) считается самой мощной в регионе, и она способна обеспечить там безопасность не только России, но и ее партнеров. Являясь оперативным объединением ВМФ России, КФ включает в свой состав соединения надводных кораблей, вспомогательных и поисково-спасательных судов, авиацию, береговые войска, части тылового, технического и специального обеспечения. В апреле 2017 и в июле 2018 г. РФ проводила на Каспийском море масштабные военные учения с боевыми стрельбами, основной задачей которых стало поражение наземных, морских и воздушных объектов условного противника «при ведении многосферной операции с практическим нанесением авиационных ударов на морском полигоне» [8].

Военное присутствие на Каспии позволяет России контролировать неспокойный северокавказский регион, оказывать воздействие на другие прибрежные государства, сдерживая их поползновения к открытию своих акваторий для военно-морских сил третьих стран - преимущественно США и членов Североатлантического альянса. Каспий, как показала российская операция в Сирии, оставаясь внутренним водоемом, может одновременно использоваться для запуска крылатых ракет. Так, 7 октября 2015 г. корабли КФ «Дагестан», «Углич», «Град Свияжск» и «Великий Устюг» выпустили 26 крылатых ракет морского базирования «Калибр» по объектам запрещенной в России террористической группировки «Исламское государство» в Сирии, поразив 11 целей на расстоянии 1,5 тыс. км. [9].

В советские годы основным пунктом базирования КФ являлся Баку. После распада СССР штаб и значительную часть подразделений КФ РФ перевели в Астрахань (в 1992 г.). Однако эта дислокация со стратегической точки зрения рассматривалась военными как недостаточно выгодная. Тем более что перед РФ во втором десятилетии XXI в. встали новые задачи по 
обеспечению национально-государственных интересов в Каспийском регионе и, в частности, проблема противодействия терроризму.

Исходя из изменившейся военно-политической обстановки и в связи с новыми задачами по обеспечению в регионе национальногосударственных интересов России, Министерство обороны РФ нацелилось на увеличение возможностей дислоцированного на Каспии оперативного объединения ВМФ, для чего было решено перевести КФ из Астрахани в дагестанский Каспийск. Объявивший об этом 2 апреля 2018 г. министр обороны РФ Сергей Шойгу пояснил, что Каспийск отличает более выгодная локация - близость к центральному участку моря, что позволяет размещать здесь крупные надводные корабли, оснащенные высокоточным оружием. Согласно оценке коммерческого директора журнала «Арсенал Отечества» А.Леонкова, «с вводом в строй новой базы ... Россия сможет надежно прикрыть союзников в Закавказье, Центральной Азии и на Ближнем Востоке», тем более что, благодаря комплексам «Калибр», расширяется и «зона поражения Каспийской флотилии» [10].

Основные цели КФ - охрана прибрежной акватории, борьба с браконьерством, защита национальных интересов в районах добычи нефти. Подобные цели декларируются и другими государствами, имеющими выход к Каспийскому морю. Однако в количественном и качественном отношении их военно-морские силы заметно уступают российским.

По своему потенциалу ВМС Исламской Республики Иран (ИРИ) занимают на Каспии второе место после России, несмотря на то что основную их часть Иран держит в более значимом для его безопасности Персидском заливе. Военно-морские силы (BMC) Армии Ирана в зоне Каспийского моря, а также морские подразделения Корпуса стражей исламской революции (КСИР) располагаются на трех базах Южного Каспия с командованием в порту Бендер-Энзели. Особенностью иранской флотилии является отсутствие в ней крупных кораблей: она формируется в основном из небольших быстроходных катеров (так называемый «москитный флот»), вооруженных часто ракетами малой дальности.

ВМС Ирана предназначены в основном для несения патрульной службы в национальной морской экономической зоне и ведения разведки деятельности флотов других прикаспийских государств. В то же время с 2013 г. Ираном на Каспии постоянно проводятся масштабные учения, на которых отрабатывается защита морских путей и торговых судов, оборона береговых военных и гражданских объектов.

Подходы Ирана к проблеме безопасности в Каспийской зоне определяются целями долгосрочной стратегии Исламской Республики, вынужденной десятилетиями существовать в условиях непрекращающегося внешнего 
давления и санкционного режима. Антииранские санкции, существовавшие до подписания в 2015 г. Совместного всеобъемлющего плана действий по иранской ядерной программе, были полностью восстановлены Соединенными Штатами 7 августа и 5 ноября 2018 г. Объектами санкций стала нефтяная отрасль Ирана, которая составляет основу экономики страны, а также банковская структура, судостроение, морские перевозки, ряд других отраслей экономики.

Ограничения касаются не только Ирана, но и всех стран, которые продолжат с Тегераном сотрудничество по санкционным направлениям. В результате этих действий нынешней американской администрации, антииранская стратегия которой в значительной степени формируется под воздействием Израиля и произраильского лобби в самих США, пространство для маневра Ирана на Ближнем Востоке и в Персидском заливе сужается. А вот на Каспии Иран в полном объеме смог сохранить свое военное присутствие, что важно для этого ближневосточного и прикаспийского государства в плане реализации некоторых направлений его международной политики.

Таков давний проект судоходного Трансиранского канала, который Иран предполагает проложить к 2030 г. из Каспия к Персидскому заливу. Для соседей Ирана, особенно для Казахстана и Туркменистана, отрезанных от Мирового океана, постройка канала сулит несомненную выгоду: им открывается перспектива выхода к Индийскому океану. Ввод канала в действие к тому же может создать конкуренцию Турции, которая, благодаря монопольному контролю над Черноморскими проливами, практически единолично распоряжается проходом в Черноморско-Каспийский регион иностранных судов (в том числе и военных). Однако имеются и минусы: проект с 1997 г. находится под санкциями США, а перспектива прокладки канала исключительно по территории Ирана означает для других стран полную зависимость от его политики - подчас достаточно непредсказуемой.

Важное значение придает Иран и другому инфраструктурному проекту - «Север-Юг», который, по замыслу, должен обеспечить поставку через Иран грузов из Индии и Персидского залива в Западную и Северную Европу. В марте 2019 г. в Иране состоялось торжественное открытие нового участка транспортного коридора «Север-Юг»- железной дороги, которая свяжет прикаспийский город Решт с Казвином, находящимся на северо-западе Исламской Республики.

Сосед Ирана - Азербайджан располагает на Каспии достаточно большим флотом, часть которого досталась республике при разделе Каспийской флотилии СССР (Азербайджан получил тогда $30 \%$ ее кораблей), а часть появилась в годы независимого развития. Азербайджан сумел почти полностью сохранить доставшееся ему от СССР военно-морское наследство, 
что позволило ВМС республики по количественным показателям занять в зоне Каспийского моря третье место после российской КФ и ВМС Армии Ирана.

До недавнего времени основным пунктом базирования ВМС Азербайджана оставался порт Баку, где расположен Главный штаб ВМС и находится Азербайджанское высшее военно-морское училище. 25 июня 2015 г. Азербайджан открыл взамен полностью ликвидированной Бакинской военно-морской базы новую базу для своего военно-морского флота в поселке Пута (Гарадагский район Баку). В планах азербайджанского военного ведомства - строительство новых кораблей и модернизация старых.

Казахстан официально не имел к моменту обретения независимости военно-морского флота, и охрану принадлежащих ему нефтеносных районов взяли на себя в начале 1990-х гг. российские боевые корабли. Однако 2 апреля 1993 г. президент Назарбаев подписал указ о создании военно-морских сил, а 7 мая 2003 г. последовал указ президента «О мерах по дальнейшему совершенствованию структуры Вооруженных сил Республики Казахстан».

В Казахстане была разработана концепция развития ВМС, сформированы основные силы, в состав которых вошли бригады береговой охраны (морская пехота), береговая артиллерия, Каспийская флотилия. Главной базой ВМС стал морской порт Актау, а дополнительной - порт Баутино. Это говорит о том, что свое присутствие в акватории Каспийского моря Казахстан намерен использовать не только в экономических, но и в военных целях.

Туркменистан после распада СССР при разделе Каспийской флотилии отказался от своей доли (25\%) в пользу России, совместно с которой эта центральноазиатская республика долгое время охраняла свои водные рубежи. Создание ВМС Туркмении и военно-морской базы в городе Туркменбаши (бывший Красноводск) началось в 2009 г. Тогда же была принята Военная доктрина Туркменистана, закрепившая нейтральный статус государства, его неприсоединение к военным союзам и блокам и включившая запрет на размещение на территории республики иностранных военных баз. Следовательно, возможности военного присутствия в стране иностранных государств исключены, однако это не мешает Туркменистану активно сотрудничать при формировании своего военного флота как с соседями по Каспию Ираном и Россией, так и с нерегиональными государствами - США и Турцией. Последняя остается главным партнером Туркменистана в области военно-морского строительства.

Зафиксированный в «Конвенции о правовом статусе Каспийского моря» фактический запрет на размещение на берегах Каспия военных баз третьих государств значительно снижает вероятность подключения нерегиональных государств к потенциальным спорам о недрах морского водоема. 
Подрываются и условия для развертывания широкомасштабного вооруженного конфликта в этом регионе мира. Здесь главные вызовы интересам России и Ирана исходят от США, которые еще в 1996 г. объявили ЧерноморскоКаспийский регион зоной своих стратегических интересов.

$\mathrm{C}$ геополитической точки зрения Каспий обеспечил бы Пентагону доступ к Центральной Азии (с ее ресурсами нефти и газа), северным провинциям Ирана и южным регионам России. По мнению российского эксперта А.Шустова, военное базирование в районе Каспия было для США стратегически столь же выгодно, как и присутствие в Афганистане [11]. Именно поэтому США стали налаживать сотрудничество с различными силовыми структурами ряда прикаспийских государств, пытаться наращивать там свое политическое влияние.

Приоритетное внимание США обращено на три прикаспийских государства, являющихся участниками программы НАТО «Партнерство во имя мира», - Азербайджан, Казахстан и Туркменистан. С их руководством представители политических и военных ведомств США постоянно проводят закрытые двусторонние переговоры, в то время как деятельность американских военных компаний и их партнеров (израильских, турецких, европейских) направляется на вытеснение России с рынка вооружений и военнотехнического оснащения армий и флотов прикаспийских государств.

Осуществить в портах Азербайджана и Туркменистана свое долгосрочное военное присутствие Соединенным Штатам не удалось, а вот с Казахстаном были налажены более прочные военно-политические контакты. Их углубление стало особенно заметным на фоне начавшегося с 2014 г. резкого обострения российско-американских отношений, в том числе и в военной сфере. Еще в 2015 г. Россия приняла решение о прекращении транзита грузов НАТО и США через свою территорию. 19 апреля 2018 г. российская авиакомпания «Волга-Днепр» отказалась от дальнейшего сотрудничества с Североатлантическим альянсом по перевозке военных грузов. И тогда США интенсифицировали переговоры с Казахстаном о возможности использования его портов в качестве транзитных пунктов для доставки своих военных грузов в Афганистан через Каспийское море.

Ускорило положительное решение Казахстана в пользу американской стороны событие, внешне не связанное с проблемой Каспия, - внезапный арест в конце 2017 г. активов Национального фонда Казахстана (22 млрд долл.), которые находились на хранении в Bank of New York Mellon и были заморожены по иску малоизвестного молдавского бизнесмена Анатолия Стати и его компании к правительству Казахстана.

Нурсултану Назарбаеву, отправившемуся в январе 2018 г. в Вашингтон для встречи с президентом Дональдом Трампом, удалось договориться о 
снятии ареста, но сразу после этого Казахстан дал согласие на использование американскими военными своих портов в Каспийском море. В апреле казахстанский парламент ратифицировал Протокол о внесении изменений в подписанное 20 июня 2010 г. двустороннее казахстанско-американское Соглашение [12], а 5 мая 2018 г. Назарбаев подписал закон, разрешающий американский транзит в Афганистан через Казахстан и включающий в маршрут транспортировки грузов каспийские порты Актау и Курык [13].

Перспектива появления в акватории Каспия - а значит, в российском приграничье - судов, перевозящих американские военные грузы, была расценена в Москве как крайне нежелательная и напрямую угрожающая российским государственным интересам. Об опасениях РФ по поводу подключения Казахстана к военно-логистическому планированию США на Каспии проинформировал своего казахстанского коллегу министр иностранных дел России Сергей Лавров в ходе встречи министров иностранных дел стран членов ОДКБ в Алматы 11 июня 2018 г. По оценке же неназванного российского дипломата, на которого сослалась газета «Коммерсантъ», «в маршруте с использованием каспийских портов нет экономической и логистической целесообразности... американцам это нужно для присутствия на Каспии, чтобы здесь появилась их инфраструктура» [14].

Пресс-служба Посольства Республики Казахстан в Российской Федерации, назвав публикации в российских СМИ и интернет-ресурсах по вопросу использования ВМС США казахстанских портов на Каспийском море «безосновательными измышлениями», отметила, что применительно к проблеме американского транзита «речь идет об общих усилиях всего международного сообщества по содействию в стабилизации Афганистана» [15].

Принятые в 2018 г. «каспийской пятеркой» решения, нацеленные на превращение Каспия в закрытый для третьих стран водоем, отдалили возможность осуществления проектов Пентагона по базированию в районе Каспийского моря и заставили американское военное ведомство сосредоточиться на менее масштабных инициативах - в частности, связанных с подготовкой спецподразделений в Азербайджане и Казахстане. Планам США/НАТО закрепиться на Каспии мешают и сложившиеся в регионе в постсоветский период достаточно устойчивые форматы военнополитического сотрудничества.

Россия и Казахстан являются членами Организации Договора о коллективной безопасности, в задачу которой входит также поддержание безопасности в Каспийском регионе. Туркменистан (в силу своего нейтрального статуса) и Азербайджан (формально по причине отсутствия прорыва в решении нагорно-карабахского конфликта) не входят в эту международную организацию, но сотрудничают с ней по отдельным аспектам (закупки ору- 
жия, кораблестроение, избирательное участие в военных учениях, подготовка в военных учреждениях России личного состава ВМФ и пр.).

Казахстан и Россия как полноправные члены СНГ и Туркменистан как ассоциированный член Содружества вовлечены в специализированные структуры безопасности этой международной организации. Все государства «прикаспийской пятерки» входят в постоянно действующую межправительственную международную организацию Шанхайская организация сотрудничества (ШОС), где Россия и Казахстан - полноправные члены, Азербайджан является партнером по диалогу, Иран - страна-наблюдатель, а Туркменистан участвует в заседаниях ШОС в качестве приглашенного гостя. Таким образом Каспийский регион с полным основанием может быть отнесен к объектам сотрудничества между ОДКБ, СНГ и ШОС.

Необходимость коллективного реагирования на возрастание традиционных и нетрадиционных угроз в акватории Каспия, возникновение в непосредственной близости от нее военных конфликтов актуализировали вопрос о создании новой межгосударственной структуры, в задачу которой вошли бы вопросы поддержания безопасности в регионе Каспийского моря. Эта проблема обсуждалась на прошедших 5-7 апреля 2016 г. в СанктПетербурге переговорах представителей командования военно-морских сил прикаспийских государств, которые, однако, сочли преждевременным создание нового объединения взамен «каспийской пятерки», функционирующей неформально, но относительно эффективно.

Очевидно, что каждый из пяти участников международнополитического взаимодействия на Каспии имеет собственные интересы и приоритеты, которые не всегда и не во всем совпадают. Поэтому они будут искать рычаги для продолжения геополитического балансирования. Впрочем, это не помешает прикаспийским государствам достигать договоренностей на основе выверенного баланса интересов. Благодаря этому на Каспии, скорее всего, будет продолжаться формирование новой модели межгосударственного взаимодействия, которая позволяет гармонично сочетать методы дипломатии с военно-силовым обеспечением безопасности.

\section{СПИСОК ЛИТЕРАТУРЫ}

1. Overview of oil and natural gas in the Caspian Sea region. - U.S. Energy Information Administration. August 26, 2013. URL: https://www.eia.gov/beta/international/analysis_includes/regions_of_interest/Casp ian_Sea/caspian_sea.pdf (дата обращения: 27.08.2013). 
2. Договор об основах взаимоотнотений и принципах сотрудничества между Российской Федеращией и Исламской Республикой Иран. 12 марта 2001 года. URL: http://www.kremlin.ru/supplement/3290 (дата обращения 04.05.2019).

3. Малышева Д.Б. 2002. Россия и Каспийский регион: проблемы безопасного развития. М.: ИМЭМО РАН.

4. Заявление президентов Азербайджсанской Республики, Исламской Республики Иран, Республики Казахстан, Российской Федерации и Туркменистана, 29 сентября 2014 года. URL: http://news.kremlin.ru/ref_notes/4754 (дата обращения: 30.09.2014).

5. Конвенция о правовом статусе Каспийского моря, 12 августа 2018 года. URL: http://www.kremlin.ru/supplement/5328 (дата обращения: 02.09.2018).

6. Конщепиия внешней политики Российской Федеращии. URL: http://publication.pravo.gov.ru/Document/View/0001201612010045?index=1\&ra ngeSize=1 (дата обращения: 01.12.2016).

7. Указ Президента Российской Федеращии от 20.07.2017 г. № 327 «Об утверждении Основ государственной политики Российской Федераџии в области военно-морской деятельности на период до 2030 года». URL: http://www.kremlin.ru/acts/bank/42117 (дата обращения: 04.05.2019).

8. На Каспии начались многосферные учения военной авиаџии России. URL: http://armiya.az/ru/news/135175/На-Каспии-начались-многосферныеучения-военной-авиации-России (дата обращения: 16.07.2018).

9. Минобороны РФ опубликовало видео ракетных стрельб по позищиям ИГ из акватории Каспийского моря. URL: https://russian.rt.com/article/121932 (дата обращения: 07.10.2015).

10. Заквасин А. Из Астрахани в Дагестан: почему Каспийская флотилия меняет прописку. URL: https://russian.rt.com/russia/article/499196kaspiiskaya-flotiliya-baza-dagestan (дата обращения: 02.04.2018).

11. Шустов А. Вокруг статуса Каспия развернулась новая интрига. Евразия Эксперт, 28.06.2018. URL: http://eurasia.expert/vokrug-statusa-kaspiyarazvernulas-novaya-intriga (дата обращения: 30.06.2018).

12. Соглашение между Правительством Республики Казахстан и Правительством Соединенных Штатов Америки об обеспечении коммерческого железнодорожного транзита специиального груза через территорию Республики Казахстан в связи с участием Соединенных Штатов Америки в усилиях по стабилизаџии и восстановлению Исламской Республики Афганистан. URL: http://adilet.zan.kz/rus/docs/Z100000300_ (дата обращения: 10.05.2019). 
13. Закон о ратификаџии Протокола о внесении изменения в Соглашение между Правительством Республики Казахстан и Правительством Соединенных Штатов Америки об обеспечении коммерческого железнодорожного транзита специального груза через территорию Республики Казахстан в связи с участием Соединенных Штатов Америки в усилиях по стабилизации и восстановлению Исламской Республики Афганистан. URL: http://online.zakon.kz/Document/?doc_id=31081954 (дата обращения: 19.04.2018).

14. Москва выговорилась в адрес союзников. - Коммерсантъ, 11.06.2018. URL: https://www.kommersant.ru/doc/3656500 (дата обращения: 12.06.2018).

15. О материалах в российских СМИ, посвященньх использованию ВМС США казахстанских портов на Каспийском море, 26.04.2018. URL: http://www.kazembassy.ru/rus/press_centr/novosti/?cid=0\&rid=1744 (дата обращения: 30.04.2018). 